\title{
Electrical Characteristics of Polyvinyl Chloride with Wollastonite Filler for High Voltage Outdoor Insulation Material
}

\author{
M. M. Yaacoba, N. Kamaruddina*, N. A. Mazlanª, N. F. Noramata , A. Aman , M. A. Alsaedia \\ anstitute of High Voltage and High Current, Faculty of Electrical Engineering, Universiti Teknologi Malaysia, 81310 UTM Johor Bahru, Johor, Malaysia \\ ${ }^{b}$ Faculty of Electrical Engineering, Universiti Teknikal Malaysia Melaka, Locked Bag 1752, Durian Tunggal, 76109, Melaka, Malaysia
}

*Corresponding author: nadiahkmd@gmail.com

\section{Article history}

Received :15 February 2013

Received in revised form :

10 June 2013

Accepted :16 July 2013

Graphical abstract

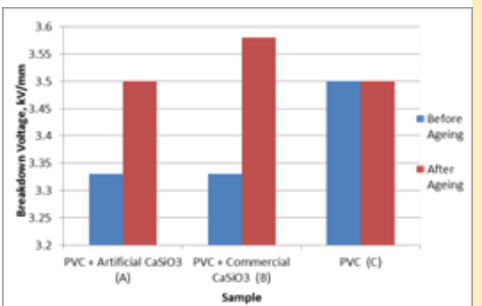

\begin{abstract}
Even though polymer composite materials have been widely used as an outdoor insulation material, their life expectancy is still unknown. Thus, to develop a better insulation, it is important to determine the electrical properties of the polymeric materials. As mentioned in previous researches, adding filler to the polymer will help to increase the performance of insulating materials. In this paper, a new polymeric insulation material for high voltage application, Polyvinyl Chloride (PVC) with the addition of Wollastonite $\mathrm{CaSiO} 3$ filler is presented. It was expected that the combination of filler with PVC would give better result when experiencing ageing process. The material would be put into tracking and erosion resistance test first and then analyzed in accordance with BSEN 60587:2007. It would then be further tested through tan delta and dielectric strength test. Comparison would then be made between the PVC with filler and PVC without filler based on the result obtained from the experiment. However, not all electrical testing showed satisfactory results and further testing should be conducted.
\end{abstract}

Keywords: Polyvinyl chloride insulator; filler; hydrophobicity; physical properties; electrical properties; aging process; tracking erosion

\begin{abstract}
Abstrak
Walaupun bahan komposit polimer telah digunakan secara meluas sebagai bahan penebat, jangka hayat mereka masih tidak diketahui. Oleh itu, untuk membuat penebat yang lebih baik, ia adalah penting untuk menentukan sifat-sifat elektrik bahan polimer. Seperti yang dinyatakan dalam penyelidikan sebelum ini, menambah pengisi untuk polimer akan membantu untuk meningkatkan prestasi bahan penebat. Dalam jurnal ini, bahan penebat baru polimer untuk aplikasi voltan tinggi, Polyvinyl Chloride (PVC) dengan penambahan pengisi $\mathrm{CaSiO} 3$ Wollastonite dibentangkan. Ia dijangkakan bahawa gabungan pengisi tersebut dengan PVC akan memberikan hasil yang lebih baik apabila mengalami proses penuaan. Bahan itu akan dimasukkan ke dalam ujian pengesanan dan hakisan rintangan dahulu dan kemudian dianalisis mengikut BSEN 60587:2007. Ia kemudian akan terus melalui ujian tan delta dan kekuatan dielektrik. Perbandingan kemudiannya akan dibuat antara PVC dengan pengisi dan PVC tanpa pengisi berdasarkan hasil yang diperolehi dari eksperimen. Walau bagaimanapun, tidak semua ujian elektrik menunjukkan keputusan yang memuaskan dan ujian lanjut perlu dijalankan.
\end{abstract}

Kata kunci: Penebat polyvinyl chlorid; pengisi; keboleh telapan air; sifat-sifat fizikal; sifat-sifat elektrik; proses penuaan; hakisan pengesanan

\subsection{INTRODUCTION}

Insulation is one of the most important aspects in high voltage outdoor application [1]. Polymeric insulators have been used for many years for high voltage outdoor applications to replace conventional materials such as porcelain, glass and ceramic. One of the major reasons to replace ceramic materials is due to their hydrophilic properties that aid the process of dry band arcing which eventually leads to flashover. The major advantage of polymeric insulators is their low surface energy which has unchangeable hydrophobic surface property in the presence of wet condition, resulting in lower leakage current. As the leakage current is low, the flashover risk will also reduce. This property benefits the polymeric insulation to be used in heavily polluted area. Polymer insulators advantages also include light weight, higher mechanical strength to weight ratio, resistance to vandalism and better voltage withstand compared to porcelain, ceramic and glass insulators $[2,3]$.

However, the ageing performance of polymeric insulator is still in doubt. If polymeric insulators suffer from tracking and erosion for an extended period of time, it may ultimately lead to failure of the insulators $[2,4,5]$. In order to extend the service life 
and improve service effect, some properties of polymeric insulation need to be improved. As reported in previous researches, it is known that adding fillers to the polymer can improve the specific properties and reduce the cost of the composite [6-9]. Many types of filler have been used in insulation such as calcium carbonate, alumina trihydrate and glass [2, 6, 7, $10,11]$. In this paper, the commonly used filler, Wollastonite or calcium silicate $\left(\mathrm{CaSiO}_{3}\right)$ is used. Wollastonite or calcium silicate, is a natural mineral which can be found in limestone. It is reported that wollastonite can increase the performance of many products such plastics and paint, besides plastics and polymer. It can also improve the durability of the composites because of its acicular or needle-like structure [6].

This study aims to identify the potential of using the artificial wollastonite as filler combined with the existing polyvinyl chloride (PVC) as high voltage polymeric insulation. This artificial wollastonite (calcium silicate, $\mathrm{CaSiO}_{3}$ ) is sourced from seashell (calcium carbonate, $\mathrm{CaCO}_{3}$ ) and glass (silica, $\mathrm{SiO}_{2}$ ) which are from waste material that have gone through a thorough experimental process $\left(\mathrm{CaCO}_{3}+\mathrm{SiO}_{2} \rightarrow \mathrm{CaSiO}_{3}+\mathrm{CO}_{2}\right)$ as discovered by [6]. The reason of using waste material like this is to support the global environment issue, as to use renewable resources [12]. This study also aims to discover the potential of artificial Wollastonite, from being waste material to be potentially used as filler for high voltage insulating material. Besides reducing the material cost, it also will enhance the electrical properties of the insulating materials.

To develop better insulation, it is important to determine the ageing and electrical properties of the polymer insulation material. Therefore, by conducting surface tracking and erosion test according to BSEN 60587:2007, the new polymer insulation material will undergo the condition resembling the ageing process. The electrical properties of the material such as tangent loss, capacitance, insulation resistance and dielectric strength are taken before and after the ageing test. Comparisons will then be made between the PVC with filler and PVC without filler based on the experimental results. In this study, the results from the tests showed that the PVC with added filler of Wollastonite has better electrical properties after undergoing the aging or contamination process.

\subsection{EXPERIMENTAL}

\subsection{Material}

The materials used were Polyvinyl Chloride (PVC), supplied by Industrial Resins (Malaysia) Sdn. Bhd. (IRM), which was mixed with a new artificially developed filler of wollastonite or calcium silicate $\left(\mathrm{CaSiO}_{3}\right)$. The sample preparation was done at Industrial Resins (Malaysia) Sdn. Bhd. (IRM).

For comparison, another sample was also prepared, which was PVC of the same grade mixed with commercial wollastonite. The PVC cable grade was prepared as reference.

\subsection{Sample Preparation}

In this task, three samples were prepared; PVC and artificial wollastonite (AW), PVC and commercial wollastonite (CW) and PVC only. These compounds were melted and blended with a two-roll mill at $140^{\circ} \mathrm{C}$ for about 5 minutes.

After that, a mould plate with the dimension of $50 \mathrm{~mm} \mathrm{x}$ $120 \mathrm{~mm} \times 6 \mathrm{~mm}$ (refer to [13]) with the respective compound in it was pressed using hot pressed machine at $180^{\circ} \mathrm{C}$ for 8 minutes, followed by cooling for 5 minutes. A total of 15 samples were made, in which 5 were PVC/AW, 5 were PVC/CW and 5 others were PVC only. The lists of samples and the compounds are shown in Table 1.

Table 1 List of sample

\begin{tabular}{cccc}
\hline $\begin{array}{l}\text { Compound } \\
\text { Sample }\end{array}$ & $\begin{array}{c}\text { Polyinyl } \\
\text { Chloride } \\
(\text { PVC) }\end{array}$ & $\begin{array}{c}\text { PVC }+ \\
\text { Artificial } \\
\text { Wollastonite } \\
\left(\mathbf{C a S i O}_{3}\right)\end{array}$ & $\begin{array}{c}\text { PVC + } \\
\text { Commercial } \\
\text { Wollastonite } \\
\left(\mathbf{C a S i O}_{3}\right)\end{array}$ \\
\hline A1 - A5 & - & $\checkmark$ & - \\
B1 - B5 & - & - & $\checkmark$ \\
C1 - C5 & $\checkmark$ & - & - \\
\hline
\end{tabular}

\subsection{Surface Tracking and Erosion Resistance}

The BS EN 62039:2007 [14] defines the important properties or minimum requirements of polymeric insulation materials for outdoor use. One of the properties is the resistance to tracking and erosion with the minimum requirements as class $1 \mathrm{~A} 3,5$. The details and test standard can be referred to BS EN 60587:2007 [13]. Inclined plane test method was used according to BS EN 60587:2007. This test was conducted to determine the surface resistance of the samples against erosion and tracking. The test set-up is shown in Figure 1.

According to BS EN 60587:2007, the specimen will be put through a preferred test voltage constantly for six hours. The constant tracking voltage is the highest withstood by all specimens without failure. As for this paper, the voltage injected was $3.5 \mathrm{kV}$, with contaminant flow rate from the pump of $0.3 \mathrm{ml} /$ minute and power resistance of $22 \mathrm{k} \Omega$. Such parameters were selected as per BS EN 62039:2007 and BS EN 60587:2007. A measurement system was set up to monitor and capture the leakage current data. The measurement system consisted of measuring and protection units which act as a sensor and a protection circuit. A National Instrument DAQ card was used as a converter to convert the analog signal into digital signal to be displayed on the computer. On the computer, Labview software was used to monitor and analyze the leakage current (LC) data.

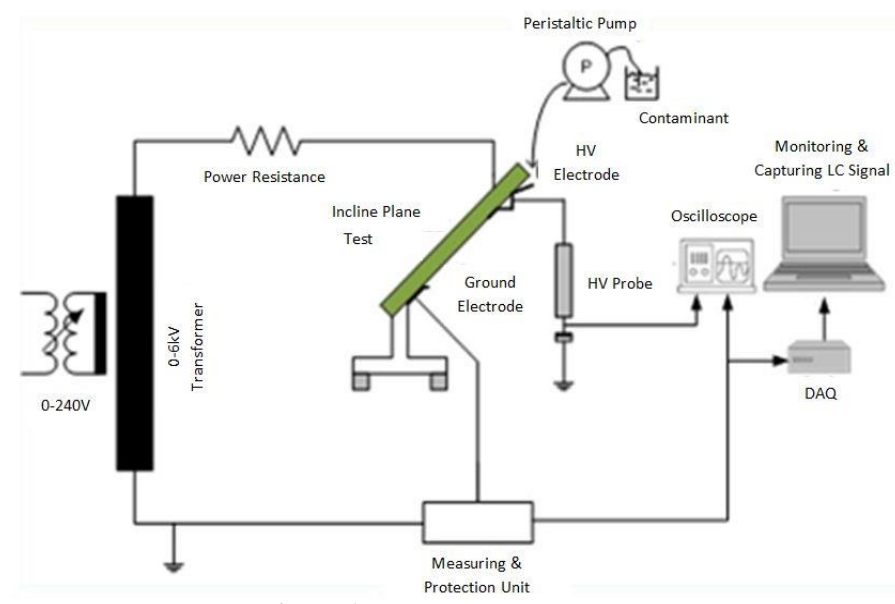

Figure 1 Inclined plane test set-up

\subsection{Tangent Delta and Capacitance}

Tangent delta test set was used to determine the loss of the test samples after the ageing test was completed. Data such as ambient temperature, humidity, and number of voltage injection were entered to ensure the results' accuracy. The samples, as in Table 1, were injected with voltage of $10 \mathrm{kV}$. After repeating 10 cycles for 
each sample, the data showing the tangent loss and capacitance values were obtained.

\subsection{Dielectric Strength or Breakdown Test}

$\mathrm{AC}$ voltages were generated to test the specimens using circuit as shown in Figure 2. This circuit comprised of step-up transformer, rod-plane electrodes, discharge rod, capacitor, and resistor. The HVAC generator was able to generate from $1 \mathrm{kV}$ to $100 \mathrm{kV}$. The test specimens used were the same ones that had been used for tracking and erosion test, dimension of $50 \mathrm{~mm} \times 120 \mathrm{~mm} \times 6 \mathrm{~mm}$. This was done to compare the performance of the sample before and after the ageing process. The dielectric breakdown strength was measured by applying high voltage stress to the sample at room temperature. The sample was then inserted in between the rod-plane electrodes.

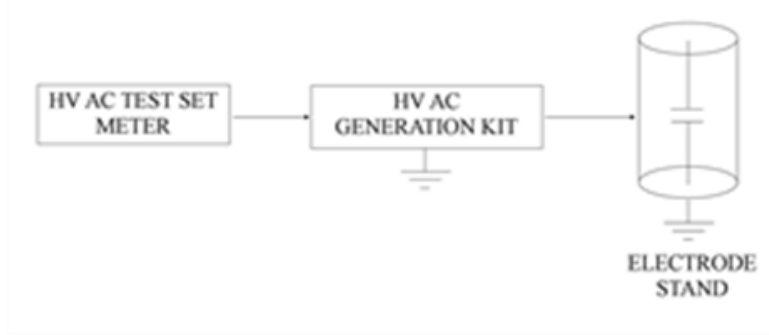

Figure 2 Breakdown test setup

\subsection{RESULTS AND DISCUSSION}

As mentioned earlier, the electrical characteristic parameters measured were tangent delta, capacitance and dielectric strength, The results obtained will be discussed in this paper.

\subsection{Surface Tracking and Erosion Resistance}

The main analysis on this paper was based on the inclined-plane tracking and erosion of insulating materials, a test used for the materials. In this analysis, we only considered the physical appearance of the materials. The results of physical appearance of tracking erosion were as shown in Table 2.

From Table 2, X represents the unsatisfied condition while $\checkmark$ presents the satisfied condition based on the observations from the inclined plane test. The minimum requirement that a polymeric insulation needed to pass based on BS EN 62039:2007 was 1A3,5b from BSEN 60587:2007 which stated that "If all five specimens survive 6hour at $3.5 \mathrm{kV}$ and if any specimens fail at $4.5 \mathrm{kV}$ less than 6hours". Table 2 shows that all three types of samples (PVC/AW, PVC/CW, PVC only) fulfilled all the physical characteristics appearance condition as mentioned in the table under tracking erosion test. From the result, it shows that all three types of sample showed promising results. In this experiment, the effect of the filler was not really significant as it only required visual supervision on the physical appearance or the surface of the samples. However, since the results of the PVC/AW sample satisfied the minimum requirement according to the standard, this sample was concluded potential to be used as insulation. Figure 3 shows the example of the physical appearance of insulation materials after the inclined plane test. This newly developed insulation materials were preferred for outdoor high voltage applications because of their low propensity to the tracking produced by surface discharges, which in this inclined planed test served the simplest screening test to establish the suitability of the material for the outdoor use [15].

Table 2 Satisfied condition that leads to physical appearance of tracking erosion resistance of the insulation materials condition

\begin{tabular}{cccc}
\hline Condition & $\begin{array}{c}\text { The Voltge Pass } \\
\text { 6 hours } \\
\text { Continuously } \\
\text { Injecting } \\
\text { Voltage }\end{array}$ & $\begin{array}{c}\text { Hole on the } \\
\text { test specimens } \\
\text { surface }\end{array}$ & $\begin{array}{c}\text { Exceeds } \\
\text { 25mm from } \\
\text { the bottom } \\
\text { mark of } \\
\text { specimens }\end{array}$ \\
\hline A1 & $\checkmark$ & $X$ & $X$ \\
A2 & $\checkmark$ & $X$ & $X$ \\
A3 & $\checkmark$ & $X$ & $X$ \\
A4 & $\checkmark$ & $X$ & $X$ \\
A5 & $\checkmark$ & $X$ & $X$ \\
B1 & $\checkmark$ & $X$ & $X$ \\
B2 & $\checkmark$ & $X$ & $X$ \\
B3 & $\checkmark$ & $X$ & $X$ \\
B4 & $\checkmark$ & $X$ & $X$ \\
B5 & $\checkmark$ & $X$ & $X$ \\
C1 & $\checkmark$ & $X$ & $X$ \\
C2 & $\checkmark$ & $X$ & $X$ \\
C3 & $\checkmark$ & & $X$ \\
C4 & $\checkmark$ & $X$ & $X$ \\
C5 & & $X$ & $X$ \\
\hline
\end{tabular}

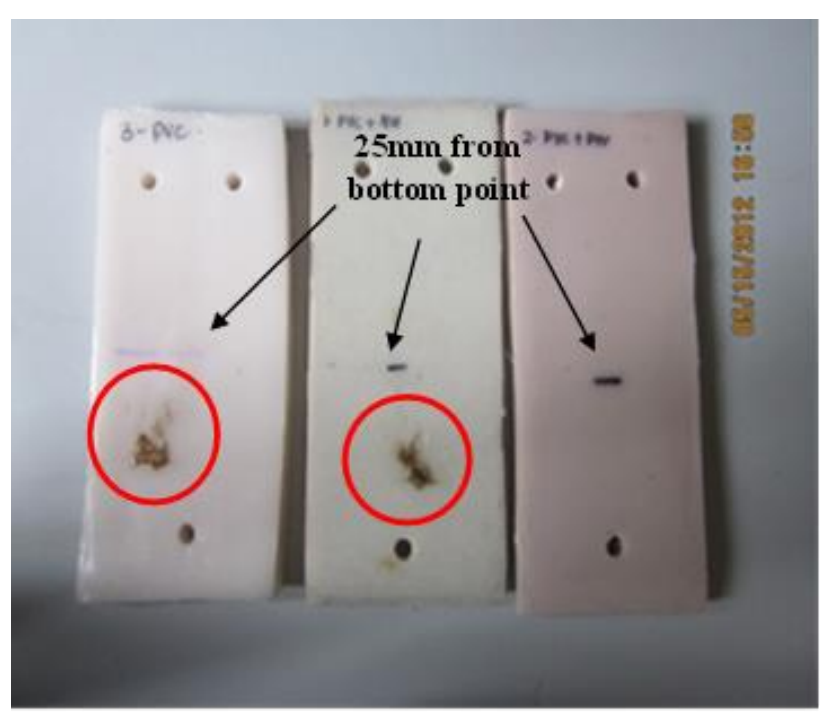

Figure 3 The physical appearance of insulation materials after the inclined plane test.

The investigation focused on the behavior in the presence of electrical arcs. This is based on the stance that polymeric materials have lower thermal resistivity compared to porcelain and glass type insulators [16]. The formation of dry band arcing during the inclined plane test was the main factor to the production of the track and erosion of the surface materials. Leakage current is the main factor that contributes to dry band arching in the presence of combination between wet 
contamination and electrical stress $[15,17]$. This dry band arching contributes to the damage of the surface insulation materials. Two modes of degradation for polymeric insulation materials that can be formed due to this leakage currents phenomenon are [15]:

i) Formation of track which is partially by conducting thecarboneous path on the surface that can reduce the insulation function

ii) A progressive material loss due to the formation of degradation by-products, causing erosion of the surface insulation

However, in degradation of materials, the type faced also depends on the composition of the polymeric chemical and the severity of the discharge activity [15]. Another common method in predicting the degradation is by monitoring the leakage currents pattern [15]. Therefore, Labview software was used in the experiment to capture the leakage currents pattern for the material.

\subsection{Tangent Delta and Capacitance}

Dissipation Factor is one of the important electrical insulation properties that are used to measure the loss rate of power in dissipative system. It is also used to determine the quality of the insulator to predict the remaining life expectancy of the insulator. A perfect insulator should have nearly zero dissipation factor value or the angle $\delta$ should be nearly zero. Figure 4 shows the average value of dissipation factor while Table 3 shows the data recorded during experiment.

Table 3 The tangent delta measurement

\begin{tabular}{cccccccc}
\hline Sample & \multicolumn{2}{c}{$\begin{array}{c}\text { PVC + Artificial } \\
\text { Wollastonite } \\
\left(\mathbf{C a S i O}_{3}\right)\end{array}$} & \multicolumn{2}{c}{$\begin{array}{c}\text { PVC }+ \\
\text { Commercial } \\
\text { Wollastonite } \\
\text { (CaSiO })\end{array}$} & & & PVC \\
Number & $\begin{array}{c}\text { Before } \\
\text { Ageing }\end{array}$ & $\begin{array}{c}\text { After } \\
\text { Ageing }\end{array}$ & $\begin{array}{c}\text { Before } \\
\text { Ageing }\end{array}$ & $\begin{array}{c}\text { After } \\
\text { Ageing }\end{array}$ & $\begin{array}{c}\text { Before } \\
\text { Ageing }\end{array}$ & $\begin{array}{c}\text { After } \\
\text { Ageing }\end{array}$ \\
\hline 1 & 0.270 & 0.949 & 0.292 & 0.883 & 0.276 & 0.910 \\
2 & 0.307 & 0.902 & 0.248 & 0.869 & 0.237 & 0.863 \\
3 & 0.206 & 0.910 & 0.204 & 0.868 & 0.196 & 0.837 \\
4 & 0.184 & 0.899 & 0.203 & 0.873 & 0.190 & 0.853 \\
5 & 0.178 & 1.03 & 0.183 & 0.898 & 0.175 & 0.837 \\
Average & 0.229 & 0.938 & 0.226 & 0.8782 & 0.2148 & 0.86 \\
\hline
\end{tabular}

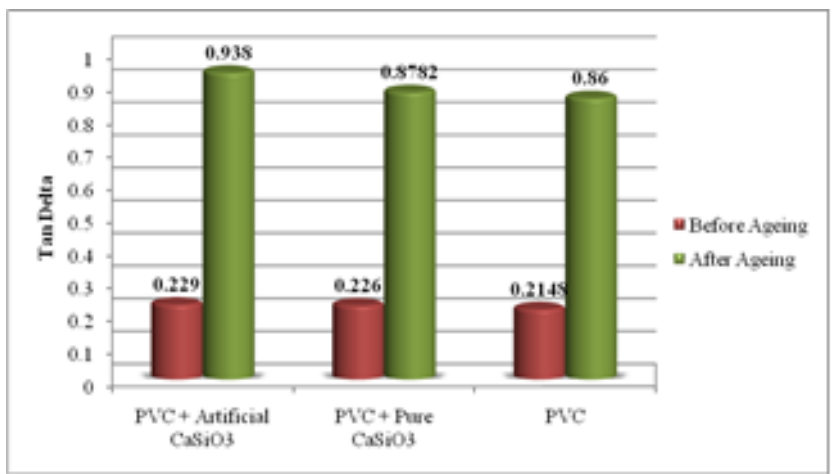

Figure 4 Average value of tan delta

From the Figure 4, the average value of $\tan \delta$ measurement before the ageing test for PVC with artificial wollastonite, AW $\left(\mathrm{CaSiO}_{3}\right)$ was 0.229 , PVC with commercial wollastonite, $\mathrm{CW}$
$\left(\mathrm{CaSiO}_{3}\right)$ was 0.226 and PVC was 0.2148 . These values showed that the materials used in this paper were good insulators since the values obtained were small and nearly zero. However, after running the ageing test, the values of $\tan \delta$ measurement increased, as shown in the graph of Figure 4 . The average value of $\tan \delta$ measurement after the ageing test for PVC/AW was 0.938 , $\mathrm{PVC} / \mathrm{CW}$ was 0.8782 and PVC was 0.86 . This was because of the effect of ageing test that exposed the insulators to contamination and impurities that led to insulator defects like water trees, electrical trees, moisture and air pockets.

To invent a perfect insulator, the insulator should carry the properties of a perfect capacitor, similar to a parallel plate capacitor in which the insulation material separates the electrical conductors. The voltage and current phase is 90 degrees and the current flowing through the insulation is capacitive for a perfect capacitor. If impurities existed in the insulator, the resistance of the insulation would decrease, causing the resistive current to increase through the insulation. Therefore, it would no longer be a perfect capacitor and the voltage and current phase would become less than 90 degrees. This angle is called loss angle or delta $(\delta)$. Figure 5 shows the phasor diagram for an ideal capacitor and capacitor with impurities insulator.

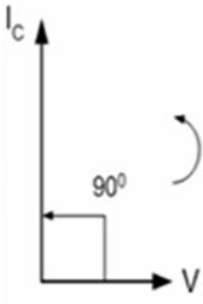

(a) An ideal capacitor

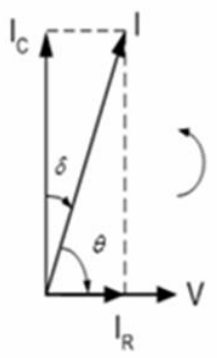

(b) Capacitor with a lossy dielectric
Figure 5 Capacitor phasor diagrams

$$
\operatorname{Tan} \delta=\frac{\mathrm{I}_{\mathrm{R}}}{\mathrm{I}_{\mathrm{C}}}
$$

The equation of the dissipation factor is shown as above. By measuring the $\mathrm{I}_{\mathrm{R}} / \mathrm{I}_{\mathrm{C}}, \tan \delta$ value can be obtained, hence can determine the quality of the insulation. From the equation, if the resistive current (leakage current) is increased, the value of $\tan \delta$ will increase and vice versa.

Figure 6 is an insulator representation. The level of resistance in the insulation is obtained by measuring the tangent of angle $\delta$. The angle would be nearly zero for perfect insulator and when the angle increases, it will show that the resistive current increases through the insulation. Greater angle indicates that the insulator is very severe in its contamination level.

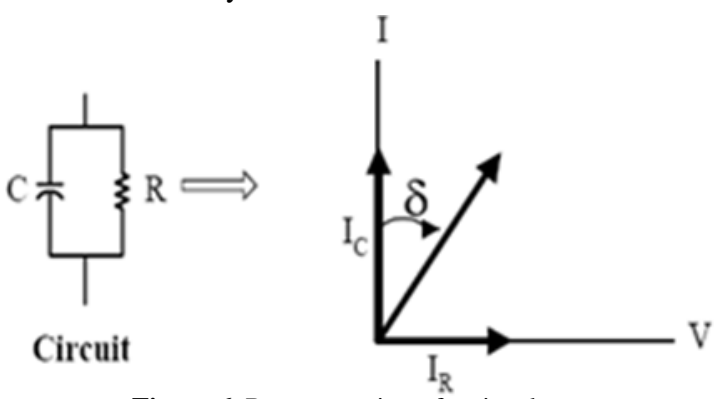

Figure 6 Representation of an insulator

From the $\tan \delta$ analysis and discussion, it was found that impurities in the insulator caused the resistive current to increase thus increasing the value of $\tan \delta$. The higher the value of $\tan \delta$, 
the possibilities for the insulator to breakdown would be higher. Before the ageing test, the value $\tan \delta$ was nearly zero. However, during the ageing test, the insulator properties gradually deteriorated because of the water treeing. Therefore, the value of $\tan \delta$ increased after the ageing test. Similarly, after the polymeric insulation was in service, the major problem occurred was the deterioration of the polymeric insulation over the years because of the water treeing in humid environment.

In previous researches, if filler was added to the polymeric material, it would help improve the polymeric properties. However, in this paper, the use of Wollastonite $\left(\mathrm{CaSiO}_{3}\right)$ filler was not sufficiently helpful in terms of insulation electrical properties. From the result obtained the percentage differences between before and after ageing was $60.75 \%$ for PVC/AW, $59.07 \%$ for $\mathrm{PVC} / \mathrm{CW}$ and $60 \%$ for PVC. Based on the percentage differences, there were no significant differences in terms of $\tan \delta$. This might be due to the failure of the insulation material to achieve a balance between matrix absorption and the dispersion of the particles [18].Therefore, it can be concluded that the use of Wollastonite filler is not suitable for PVC in terms of the dissipation factor $(\tan \delta)$. However, researchers beforehand have discovered the use of silane coupling agent to improve the dispersion and compatibility between hydrophilic fillers with hydrophobic polymer base matrix [19, 20].

Capacitance measurement was needed to ensure the insulator is perfect by obtaining perfect capacitor value. To identify whether the insulator is good, the capacitance value should be higher. Figure 7 shows the average value of the capacitance before and after ageing test while Table 4 shows the data recorded during the experiment.

Table 4 Capacitance measurements

\begin{tabular}{|c|c|c|c|c|c|c|}
\hline \multirow{2}{*}{$\begin{array}{l}\text { Sample } \\
\text { Number }\end{array}$} & \multicolumn{2}{|c|}{$\begin{array}{c}\text { PVC + } \\
\text { Artificial } \\
\text { Wollastonite }_{\left(\mathrm{CaSiO}_{3}\right)(\mathbf{p F})}\end{array}$} & \multicolumn{2}{|c|}{$\begin{array}{c}\text { PVC + } \\
\text { Commercial } \\
\text { Wollastonite } \\
\left(\mathrm{CaSiO}_{3}\right)(\mathbf{p F})\end{array}$} & \multicolumn{2}{|c|}{ PVC (pF) } \\
\hline & $\begin{array}{l}\text { Before } \\
\text { Ageing }\end{array}$ & $\begin{array}{c}\text { After } \\
\text { Ageing }\end{array}$ & $\begin{array}{l}\text { Before } \\
\text { Ageing }\end{array}$ & $\begin{array}{c}\text { After } \\
\text { Ageing }\end{array}$ & $\begin{array}{l}\text { Before } \\
\text { Ageing }\end{array}$ & $\begin{array}{c}\text { After } \\
\text { Ageing }\end{array}$ \\
\hline 1 & 33.66 & 6.054 & 34.89 & 5.687 & 28.47 & 5.65 \\
\hline 2 & 21.08 & 5.74 & 31.48 & 5.64 & 28.39 & 5.448 \\
\hline 3 & 31.46 & 5.624 & 32.12 & 5.56 & 26.06 & 5.398 \\
\hline 4 & 30.44 & 5.726 & 29.74 & 5.595 & 27.46 & 5.427 \\
\hline 5 & 34.3 & 6.498 & 33.77 & 5.492 & 29.15 & 5.55 \\
\hline Average & 30.188 & 5.9284 & 32.4 & 5.5948 & 27.906 & 5.4946 \\
\hline
\end{tabular}

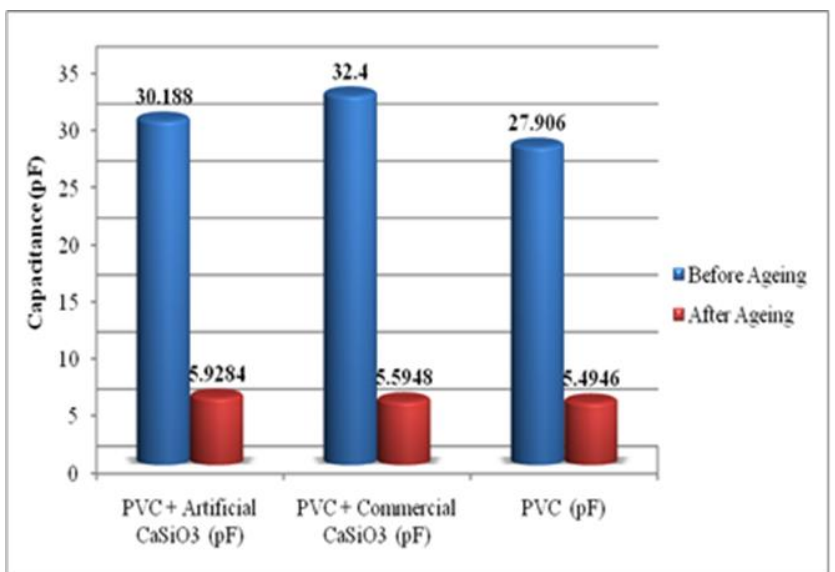

Figure 7 Average value of capacitance

From the Figure 7, the average value of capacitance before ageing test for $\mathrm{PVC} / \mathrm{AW}$ was $30.188 \mathrm{pF}, \mathrm{PVC} / \mathrm{CW}$ was $32.4 \mathrm{pF}$, and
PVC was $27.906 \mathrm{pF}$. To satisfy the condition of a good insulation, the value of capacitance must be high. From the graph, the insulation was considered as a good insulator since the capacitance value was high before the ageing test. However, after the ageing test, the insulation material became degraded by moisture and water trees, causing the capacitance value to decrease. The average value after the ageing test for PVC/AW was $5.9284 \mathrm{pF}, \mathrm{PVC} / \mathrm{CW}$ was $5.5948 \mathrm{pF}$, and $\mathrm{PVC}$ was 5.4946 $\mathrm{pF}$. This values show that the water tree during ageing process enhanced the degradation of polymeric material.

$\operatorname{Tan} \delta=\frac{\mathrm{I}_{\mathrm{R}}}{\mathrm{I}_{\mathrm{C}}}$

$I_{C}=C \frac{d v_{C}}{d t}$

From equation 1.1, the increase of the $\tan \delta$ value and resistive current value will influence the value of capacitive current, Ic to decrease. The equation 1.2 indicates that the capacitive value will decrease according to the decrease of the value of capacitive (charging) current, Ic [24].

From the $\tan \delta$ and capacitance analysis, the value of capacitance was found to decrease because of the effect of the ageing process that enhanced the insulation properties to deteriorate. When the insulation is bad, the value of $\tan \delta$ increased, hence the value of resistive current also increased, causing the capacitive value to decrease.

By comparing the three types of insulation materials used, the percentage of difference between before and after ageing was $67.17 \%$ for PVC/AW, $70.55 \%$ for PVC/CW and $67.10 \%$ for PVC. PVC with filler had high percentage value compared to the percentage value of PVC without filler. This shows that the combination of filler inside the PVC material helped improve the insulation properties to achieve higher capacitance value.

\subsection{Dielectric Strength or Breakdown Test}

Breakdown voltage is one of the most important electrical insulation properties that are used to measure the voltage value at the point where the insulation breakdown occurs. A good insulator should have high breakdown voltage value. According to BS EN 60243-1[21], the polymeric insulation materials for outdoor application must fulfill the minimum requirement of $10 \mathrm{kV} / \mathrm{mm}$ to pass the breakdown field strength test. The results for this experiment are shown in Table 5. Figure 8 shows the line chart of the breakdown voltage value before and after ageing process.

Table 5 Results of breakdown test

\begin{tabular}{lcccc}
\hline \multicolumn{1}{c}{ Sample } & $\begin{array}{c}\text { Breakdown Voltage } \\
(\mathbf{k V})\end{array}$ & \multicolumn{2}{c}{$\begin{array}{c}\text { Breakdown Voltage } \\
(\mathbf{k V / m m})\end{array}$} \\
& $\begin{array}{c}\text { Before } \\
\text { Ageing }\end{array}$ & $\begin{array}{c}\text { After } \\
\text { Ageing }\end{array}$ & $\begin{array}{c}\text { Before } \\
\text { Ageing }\end{array}$ & $\begin{array}{c}\text { After } \\
\text { Ageing }\end{array}$ \\
\hline $\begin{array}{l}\text { PVC + Artificial } \\
\text { Wollastonite }\left(\mathrm{CaSiO}_{3}\right),\end{array}$ & 20 & 21 & 3.33 & 3.5 \\
A & & & & \\
$\begin{array}{l}\text { PVC + Commercial } \\
\text { Wollastonite }\left(\mathrm{CaSiO}_{3}\right),\end{array}$ & 20 & 21.5 & 3.33 & 3.58 \\
$\begin{array}{l}\text { B } \\
\text { PVC, C }\end{array}$ & 21 & 21 & 3.5 & 3.5 \\
Average & 20.33 & 21.17 & 3.39 & 3.53 \\
\hline
\end{tabular}




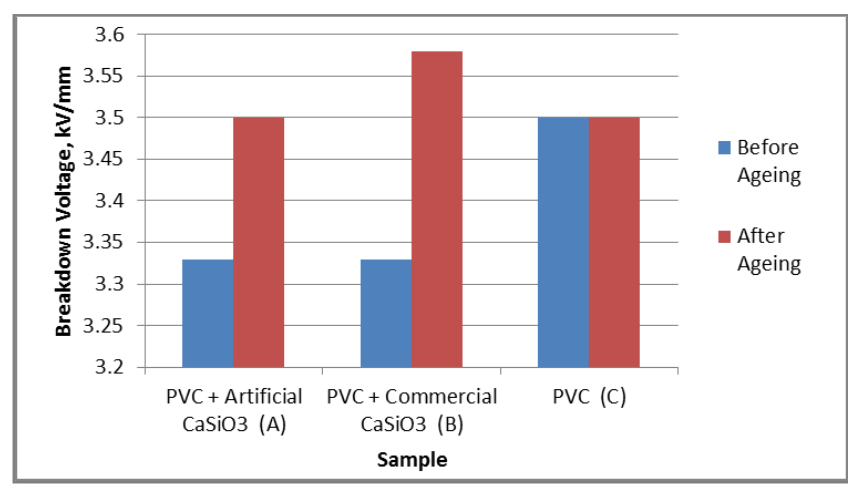

Figure 8 Breakdown voltage value for each type of samples before and after ageing

As shown in Table 5, before the ageing test, the breakdown voltage for PVC/AW was $3.33 \mathrm{kV} / \mathrm{mm}$, PVC/CW also $3.33 \mathrm{kV} / \mathrm{mm}$ and while PVC was $3.5 \mathrm{kV} / \mathrm{mm}$. These values showed that all the samples had failed the test by not reaching the minimum requirement of breakdown field strength according to the BS EN 60243-1. The same happened to the results of the breakdown field strength after the ageing process. Table 5 shows that the value of breakdown voltage after ageing for PVC/AW was $3.5 \mathrm{kV} / \mathrm{mm}$, for $\mathrm{PVC} / \mathrm{CW}$ was $3.58 \mathrm{kV} / \mathrm{mm}$, and while $\mathrm{PVC}$ without filler was $3.5 \mathrm{kV} / \mathrm{mm}$. The after-ageing breakdown voltage value showed very little increment compared to the value before ageing test. Figure 9 shows the spark which occurred during the breakdown voltage experiment.

In comparison of each type of samples, PVC material without the filler obtained slightly higher breakdown voltage value than the PVC material containing the filler for the result of before ageing. After ageing, PVC material with filler obtained slightly higher breakdown voltage value compared to the PVC material without filler. The percentage of difference between before and after ageing was $4.76 \%$ for PVC with Artificial $\mathrm{CaSiO}_{3}, 6.98 \%$ for $\mathrm{PVC}$ with Commercial $\mathrm{CaSiO}_{3}$ and $0 \%$ for PVC.

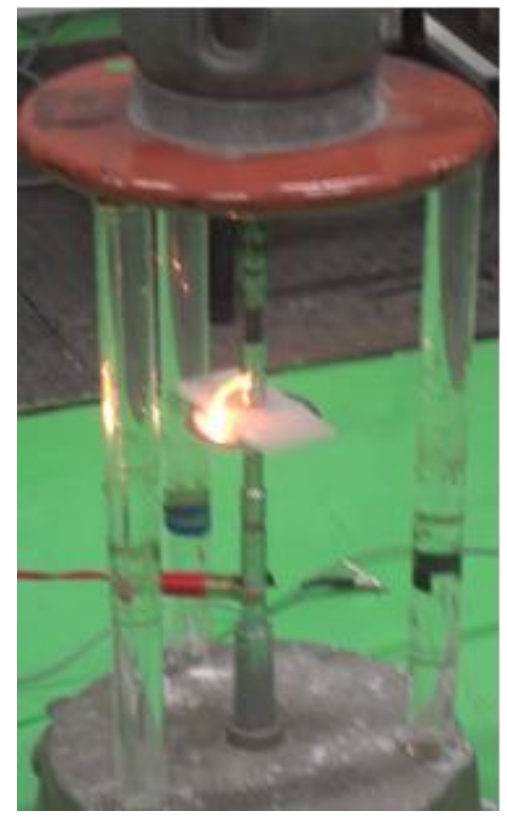

Figure 9 Breakdown voltage experiment
Meanwhile, in previous research which studied $\mathrm{PVC} / \mathrm{Calcium}$ Carbonate $\left(\mathrm{CaCO}_{3}\right)$ and $\mathrm{PVC} /$ Bentonite which vary the formulations obtained a better dielectric strength value. Table 6 shows the formulations studied in the project while Table 7 shows the results of the dielectric strength test in the project. From the graph shown in Figure 10, between both types of fillers, only $\mathrm{PVC} / \mathrm{CaCO}_{3}$ displays slight improvement in dielectric strength test value compared to PVC without filler. Moreover, $\mathrm{PVC} / \mathrm{CaCO}_{3}$ with $5 \mathrm{wt} \%$ concentration of calcium carbonate on compound was the best among all in regards to increase breakdown voltage. This indicates the effect of filler concentration on dielectric strength of insulating materials [22, 23]. From $[22,23]$ research, it can be concluded that $\mathrm{CaCO}_{3}$ was more compatible with PVC.

Table 6 Formulations studied in [22, 23] project

\begin{tabular}{cccc}
\hline Formulation & $\begin{array}{c}\text { PVC Cable } \\
\text { Grade }\end{array}$ & $\begin{array}{c}\text { Calcium } \\
\text { Carbonate } \\
\text { (FCC-200) }\end{array}$ & $\begin{array}{c}\text { Bentonite } \\
\text { (Nanofil } \\
\text { SE3000) }\end{array}$ \\
\hline F0 & 100 gram & 0 & 0 \\
F1 & 97.5 gram & 2.5 gram & 0 \\
F2 & 95 gram & 5 gram & 0 \\
F3 & 92.5 gram & 7.5 gram & 0 \\
F4 & 90 gram & 10 gram & 0 \\
F5 & 97.5 gram & 0 & 2.5 gram \\
F6 & 95 gram & 0 & 5 gram \\
F7 & 92.5 gram & 0 & 7.5 gram \\
F8 & 90 gram & 0 & 10 gram \\
\hline
\end{tabular}

Table 7 Results of the dielectric strength test in [22, 23] project

\begin{tabular}{cc}
\hline Formulation & Breakdown Voltage $\mathbf{( k V / m m )}$ \\
\hline F0 & 5.31 \\
F1 & 5.57 \\
F2 & 5.95 \\
F3 & 5.59 \\
F4 & 5.48 \\
F5 & 5.03 \\
F6 & 4.85 \\
F7 & 4.54 \\
F8 & 4.28 \\
\hline
\end{tabular}

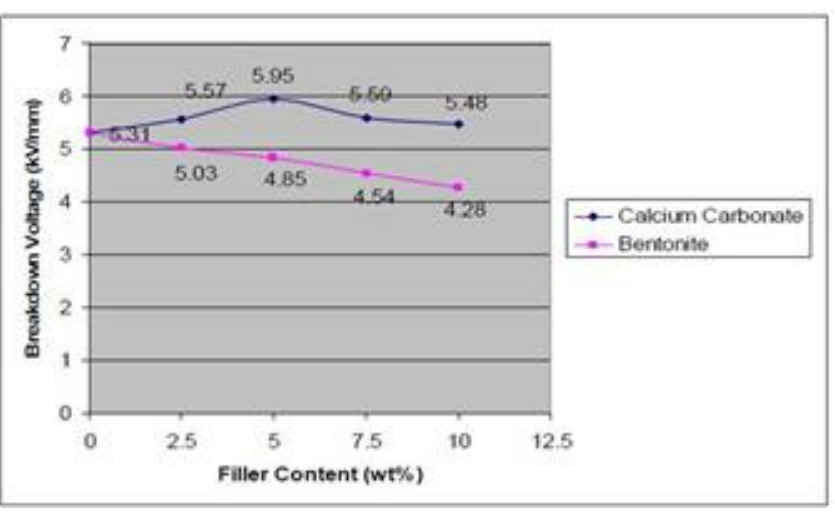

Figure 10 Comparison of the dielectric strength test results between $\mathrm{PVC} / \mathrm{CaCO} 3$ and $\mathrm{PVC} /$ Bentonite with different concentration in $[22,23]$ project

The British Standard [14] had stated the minimum requirement of breakdown field strength for a polymeric insulation under material development was $10 \mathrm{kV} / \mathrm{mm}$. From the results, it is concluded that all samples failed this test. This was 
due to the chemical formulation that might not be the optimum or the best one which can produce the strongest bond. Besides that, with correct composition of the particle or the element, the sample will be well dispersed. As the composition influenced the dispersion of the particle, it also influenced the dielectric strength. In certain cases, the incompatibility between the hydrophilic fillers and hydrophobic polymers also produced weak properties of composites $[19,20]$. The problems as mentioned before were then solved by the same researchers with the use of silane coupling agent $[19,20]$.

\subsection{CONCLUSION}

As a conclusion, both electrical and physical characteristic of Polyvinyl Chloride using Wollastonite $\left(\mathrm{CaSiO}_{3}\right)$ filler can be determined either before, during and after each different types of testing undergo the aging process. In determining the electrical and physical performance of specimens, many factors need to be considered. In this experiment, all physical tests conducted were successful while most of electrical tests did not achieve satisfactory results. This experiment should be further tested so that we can see if using this filler can improve the performance of high voltage outdoor insulation materials. As a recommendation, present researchers should study various formulations of PVC/AW and PVC/CW where the optimum composition could be obtained, thus may give better results or performance. The use of silane coupling agent should be considered since it can overcome the incompatibility problem between the hydrophilic filler and hydrophobic polymer. Hence, good property of composites can be obtained.

Since this paper is the starting point of the usage of new filler materials, certain obtained results still can be used and can be referred for further studies. Initial research shows some promising results of the usage of the new filler materials to enhance the insulating properties of outdoor insulators. It is hoped a further work could be conducted in order to improve the material performance.

\section{Acknowledgement}

The authors gratefully acknowledge the Faculty of Electrical Engineering, Universiti Teknologi Malaysia, for giving the support in this study. The authors also would like to thank Universiti Teknologi Malaysia (UTM) for the use of facilities and by awarding a Research University Grant (RUG) under vote number: 01J98.

\section{References}

[1] T. S. R. R. Karthik, Raja R. Madavan. 2012. Enhancement of Critical Characteristics of Transformer Oil Using Nanomaterials. Arabian Journal for Science and Engineering. 9.
[2] R. Hackam. 1999. Outdoor HV Composite Polymeric Insulators. Dielectrics and Electrical Insulation, IEEE Transactions on. 6: 557-585.

[3] A. J. Muhammad AKRAM, Tasneem Zahra RIZVI. 2005. Dielectric Properties of Industrial Polymer Composite Materials. Turkish Journal of Physics. 29: 355-362.

[4] J. F. Hall. 1993. History and Bibliography of Polymeric Insulators for Outdoor Applications. Power Delivery, IEEE Transactions on. 8: 376385.

[5] Z. Tiebin and R. A. Bernstorf. 1998. Ageing Tests of Polymeric Housing Materials for Non-ceramic Insulators. Electrical Insulation Magazine IEEE. 14: 26-33.

[6] A. Aman, et al. 2013. Polymeric Composite Based on Waste Material for High Voltage Outdoor Application. International Journal of Electrical Power \& Energy Systems. 45: 346-352.

[7] A. Aman, et al. 2011. Dielectric Strength of Waste Tyre DustPolypropylene (WTD-PP) for High Voltage Application. Australian Journal of Basic and Applied Sciences. 5: 1578-1583.

[8] A. Aman, et al. 2012. Dielectric property of Waste Tire DustPolypropylene (WTD-PP) Composite for High Voltage Outdoor Insulation Application. In Power Engineering and Optimization Conference (PEDCO) Melaka, Malaysia, 2012 Ieee International. 124128.

[9] A. Aman and M. M. Yaacob. 2012. Optimization of Dielectric Strength of Polymeric Composite Insulation Using Response Surface Methodology. In Power System Technology (POWERCON), 2012 IEEE International Conference on. 1-5.

[10] J. Mackevich and M. Shah. 1997. Polymer Outdoor Insulating Materials. Part I: Comparison of Porcelain and Polymer Electrical Insulation. Electrical Insulation Magazine, IEEE. 13: 5-12.

[11] J. Mackevich and S. Simmons. 1997. Polymer Outdoor Insulating Materials. II. Material Considerations. Electrical Insulation Magazine, IEEE. 13: 10-16.

[12] S. Thomas, et al. 2013. Impact of Nanomaterials on Health and Environment. Arabian Journal for Science and Engineering. 38: 457477.

[13] B. S. Institution. 2007. BS EN 60587:2007 Electrical Insulating Materials Used Under Severe Ambient Conditions-Test Methods for Evaluating Resistance to Tracking and Erosion. 1-18.

[14] B. S. Institution. 2007. PD IEC/TR 62039:2007 Selection Guide for Polymeric Materials for Outdoor use under HV Stress. 1-16.

[15] S. Venkataraman, et al. 2005. Tracking and Erosion Resistance of Polymeric Materials in Oxygen Deficient Conditions. Dielectrics and Electrical Insulation, IEEE Transactions on. 12: 595-600.

[16] R. Barsch, et al. 1999. Test Methods for Polymeric Insulating Materials for Outdoor HV Insulation. Dielectrics and Electrical Insulation, IEEE Transactions on. 6: 668-675.

[17] U. Meier. 2012. Carbon Fiber Reinforced Polymer Cables: Why? Why Not? What If? Arabian Journal for Science and Engineering. 37: 399411.

[18] G. M. a. M. Farzaneh. 2011. Survey of Micro/Nano Filler Use to Improve Silicone Rubber for Outdoor Insulators. Revision Advance Material Science. 27: 1-13.

[19] W. B. a. T. Datashvili. 2008. Chemical Modification and Characterization of Boehmite Particles. Chemistry and Chemical Technology. 2: 6.

[20] P. Blaszczak, et al. 2010. Rheology of Low-density Polyethylene + Boehmite Composites. Polymer Composites. 31: 1909-1913.

[21] B. S. Institution. 1998. BS EN 60243-1:1998 Electrical Strength of Insulating Materials-Test Methods. 24.

[22] M. Yaacob. 2008. Comparison Between Micro-filler and Nano-filler Materials on the Dielectric Strength of PVC Cable.

[23] M. Yaacob, et al. 2010. A New Polyvinyl Chloride Cable Insulation Using Micro and Nano Filler Materials. In Power Engineering and Optimization Conference (PEOCO), 2010 4th International. 221-225.

[24] Jailani, M. F. B. M. 2010. Degradation of Polymeric Power Cable Due to Water Tree Under AC Voltage. Universiti Teknologi Malaysia, PSM Thesis. 